\title{
我が国の労働者の新型コロナワクチンに対する意識と 新型コロナワクチンを接種する動機づけとの関連性
}

工藤 安 史*1，後 藤 由 紀*1，柿 原 加代子*1，吉 田 和 枝*1
榎 本 喜 彦*1，森 智 子*1，河 野 啓 子*1，堤 明 純*2

我が国の労働者の「新型コロナワクチンに対する意識」と「新型コロナワクチンを接種する動機づけ」との 関連性を検討することで,職域における新型コロナワクチン接種の推進方法について探る.2020年9月から 12 月の 間に調査を実施した.対象者は 36事業場に勤務する労働者で,解析対象者数は 2,061名であった.新型コロナワク チンに対する意識に関する項目は,ヘルスビリーフモデルを参考にして独自に作成し, 因子分析（主因子法, プロ マックス回転）を行った.因子分析の結果，「自他の命と健康を守れる」，「費用負担の容認」，「安心して生活が できる」，「安全性への信頼」という4つの因子が抽出された、「新型コロナワクチン接種への動機づけ」は,「完 全に思わない」から「完全に思う」までの9段階で対象者に回答を求め,「やや思う」から「完全に思う」までの ワクチン接種に対する肯定的な回答は $67.2 \%$ であった。「新型コロナワクチン接種への動機づけ」に関連する因 子を探る目的で,重回帰分析を行った.その結果,「自他の命と健康を守れる」，「費用負担の容認」，「安全性への 信頼」という3つの因子が,「新型コロナワクチン接種への動機づけ」と有意に関連していた.男性は女性よりも 新型コロナワクチン接種への動機づけが有意に高かった.これらの心理的な因子や性別の違いを考慮することで, 労働者の新型コロナワクチン接種の動機づけを高めることが出来る.

キーワード : 新型コロナウイルス感染症, 動機づけ, 労働者, ワクチン

\section{1 はじめに}

新型コロナウイルス感染症が,パンデミックになって いる.このような状況の下, 産業保健の領域においても, 労 働者の新型コロナウイルス感染症の拡大を防止すること は,重要である.職域の感染症対策として,3密（密集,密 閉,密接）への対策,手洗いの徹底,マスクの着用,在宅勤 務の奨励などを実施すると共に,職場全体で感染症対策 に取り組む風土の醸成なども重要である ${ }^{1-3)}$

また, 我が国では, 国民への新型コロナワクチン接種が 円滑に進められるように「予防接種法及び検度法の一部 を改正する法律」が施行された ${ }^{4}$. 都道府県知事および市 町村長が,ワクチン接種の実施主体であるが,事業主は,上 記の感染予防対策に加えて ${ }^{1-3)}$, 新型コロナワクチンの接 種を労働者に奨励することも職域における感染拡大を防 止するのに有益な手段だと思われる.

しかしながら, 新型コロナワクチンの接種は, 本人の自 由意思に基づく.したがって,労働者の新型コロナワクチ ンを積極的に接種する動機づけが低いことも考えられ， 事業場にて,このワクチンの接種率が高まらない可能性 がある.したがって,労衝者のこのワクチンを接種するこ とへの動機づけを高める心理的な因子を探る必要があ る.

この動機づけに関連する心理的な因子を探るにあた

原稿受付 2021年 2 月25日 (Received date: February 25, 2021)

原稿受理 2021年 6 月 8 日 (Accepted date: June 8, 2021)

J-STAGE Advance published date: July 6, 2021

* 1 四日市看護医療大学

*2 北里大学医学部公衆衛生

連絡先：干512-8045 三重県四日市市萱生町 1200

四日市看護医療大学 工藤安史

E-mail:kudo@y-nm.ac.jp

doi: 10.2486/josh.JOSH-2021-0004-GE
り,「新型コロナワクチンへの意識」に着目することは重 要だと考える.新型コロナワクチンは,人類が初めて経験 している新型コロナウイルス感染症対策のために作られ たものであるため,この初めてのワクチンに対して不安 を感じている労働者はいると考える.加えて,新型コロナ ワクチンは,極めて短い期間で開発され,ワクチンの開発 においても遺伝子工学的技術という新しい手法が用いら れている ${ }^{5)}$.このことは,このワクチンの有効性や有害事 象に対する労働者の懸念をさらに高めている可能性があ る.ゆえに,本研究では,「新型コロナワクチンに対する意 識」に焦点を当てる.そして,これらの意識と「新型コロ ナワクチンを接種する動機づけ」との関連性を検討する.

人々の予防的保健行動を研究する場合,ヘルスビリー フモデルという理論がある ${ }^{6-11)}$.この理論では,人々の予防 的な保健行動を促すための視点として, 罹患性(病気にな るかもしれないという認知), 重大性 (病気になった場合, 重篤な健康状態になるかもしれないという認知), 有益性 （行動することで予防に効果があるという認知）,障害性 （行動を起こすのに妨げとなることへの認知）を挙げてい る.例えば,この概念は,職域の健康診断の有効活用を労働

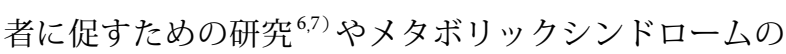
予防や改善を労働者に促す研究 ${ }^{8)}$,インフルエンザワクチ ンの接種を促す研究 ${ }^{9,10)}$,新型コロナワクチンの接種を促 す研究 ${ }^{11)}$ にも活用されている.このように,ヘルスビリー フモデルは,様々な疾病に対して,人々の予防的保健行動 を促す心理的な側面を研究するのに活用されている.

本研究では,「新型コロナワクチンに対する意識」に関 する調査項目を作成するにあたり,ヘルスビリーフモデ ルを参考にしながら，独自に項目を作成した.しかしなが ら, 本研究の目的はへルスビリーフモデルを検証するこ 
とではないため,このモデルのそれぞれ $4 つ の$ 概念(「罹 患性」,「重大性」,「有益性」,「障害性」)に完全に対応 するように項目を作成していない．

海外の先行研究において,ヘルスビリーフモデルを含 め,住民などを対象にして, 新型コロナワクチンを接種す る意思に関連する心理的な因子を探った研究が,すでに 報告されつつある ${ }^{11,12}$. しかしながら,著者らが,調べた限 りでは,我が国の労働者を対象にして、「新型コロナワク チンへ意識」を解析し,さらにこれらの意識と「新型コロ ナワクチン接種の動機づけ」との関連性を探った研究は, 見つからない.

ぞのような新型コロナワクチンの意識が,労働者の新 型コロナワクチンの接種の動機づけに関連するのか定量 化することは, 事業場として労働者にワクチン接種を促 す時に, 役立つように思われる.そこで,本研究では, 新型 コロナワクチンに対する労働者の意識を調査し, 因子分 析にて,このワクチンに対して, どのような潜在的な因子 があるのか調査する.その後, 因子分析で抽出された各因 子とこのワクチンを接種しようとする動機づけとの関連 性について明らかにする。

\section{2 方法}

\section{1 ) 調査対象と研究方法}

協力事業所は,某商工会議所を通して,事業場を紹介し て頂くと共に, 本研究の研究者らの人脈を通して, 事業場 に研究への協力依頼を行った.また, 協力の得られた事業 場から新たに紹介を受けた事業場にも調査への協力依頼 を行った。

その結果,36事業場が研究に参加し,対象者はこれらの 事業場に勤務する 3,968 名であった. 対象者数が「50名未

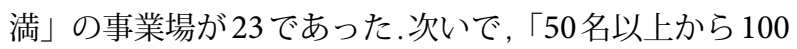
名未満」が 3 , 100 名以上から 150 名未満」が 1 , 「150名 以上から 200 名未満」が 0 , 「200名以上から 250 名未満」 が 4,「250名以上から 300 名未満」が $0,\lceil 300$ 名以上から 350 名未満」が 2 , 3550 名以上から 400 名未満」が $0,\ulcorner 400$ 名以上から 450 名未満」が 1 ,「450名以上から 500 名未満」 が 0 ,「500名以上から 550 名未満」が $0, 「 550$ 名以上から 600 名未満」が $0, \Gamma 600$ 名以上から 650 名未満」が 2 であ った。

所在地に関して, 三重県が 21 , 愛知県が 4 , 東京都が 2 , 大 阪府が 1 , 福岡県が 1 , 広島県が 1 , 宮城県が 1 , 北海道が 1 , 石 川県が 1 , 埼玉県が 1 , 神奈川県が 1 , 千葉県が 1 であった. 各 事業場の産業は, 建設業が 11 , サービス業が 9 , 製造業が 5 , 卸売り・小売業が 6 , 情報通信業が 2 , 金融業・保険業が 2 , 運輸業が1であった。

なお,患者や高齢者へのサービスを提供する医療施設 や介護施設は,ワクチン接種に業務上の大きな便益があ るように思われる.本研究の調査対象に, 医療施設や介護 施設は含まれていない.

新型コロナウイル感染症を予防するために在宅勤務な ぞを行っている事業場の場合,紙面での調査が難しい可 能性がある.したがって, 紙面による調查票の配布の
他,Webアンケートによる調査での研究参加も可能とし, 事業場の判断で,調査方法を選択できるようにした.その 結果,25の事業場が紙面アンケートでの研究参加を選択 し,11の事業場が Webアンケートでの研究の参加を選択 した.

紙面アンケートを選択した事業場では,説明文書,無記 名式の調査票,回収用封筒を配布した.そして,事業場に対 して,調査票は封筒に密封された状態で, 事業場内に設置 された回収箱を用いて回収するように依頼した.Web回 答を選択した事業場は, 事業場の担当者から労働者に対 して,説明文書と無記名式のWeb 調査票のURLをメール で配信していただいた。

\section{2) 調査期間}

調査期間は,2020年9月から 12 月までの間であった.な お,この調查時期は,わが国に扔いて新型コロナワクチン の承認前であった

\section{3) 調査項目}

SARS-CoV-2によって引き起こされる感染症名は COVID-19 と名付けられている.しかしながら, 厚生労働 省は新型コロナウイルス,および新型コロナウイルス感 染症という表現を使用して,国民への感染症対策を促し ており ${ }^{1)}$,これらの表現が国民に定着しているように思わ れる.医療の専門家ではない人々にとって,SARS-CoV-2 およびCOVID-19という表現は,分かり難い可能性があ る.ゆえに，対象者にとって分かり易い調查票を作成する ために,SARS-CoV-2およびCOVID-19という表現を避け た.

調查項目は,大きく分けて,1.「新型コロナウイルス感 染症に対する意識と新型コロナウイルス感染症に対する 検査を受ける動機づけ」,2、「新型コロナワクチンに対す る意識と新型コロナワクチン接種への動機づけ」,3.「調 査対象者の属性・基本事項」であった。

本研究は,新型コロナワクチンに対する意識とこのワ クチンを接種する動機づけに関連する因子を探る研究で あることから,「新型コロナウイルス感染症に対する意識 と新型コロナウイルス感染症に対する検査を受ける動機 づけ」に関する各項目は,本研究の解析に使用せず,第2 報として報告する予定である。「新型コロナワクチンに対 する意識と新型コロナワクチン接種への動機づけ」の具 体的な項目は,「付録」に示した。

「新型コロナワクチン接種への動機づけ」は,「新型コ ロナウイルスのワクチンが開発され,接種が可能になっ たら,私はこのワクチンを接種したい.」と質問した（「付 録」の項目 25 を参照）.対象者には，「完全に思わない」 から「完全に思う」までの9段階で回答を求めた。

次いで,「付録」の項目 1 から項目 24 までが,「新型コ ロナワクチンに対する意識」を調べるための項目であ る.以下の因子が存在すると仮説を立て, これらの項目を 作成した：「費用負担の容認 (項目 1 から項目 4)」,「安全 性への信頼（項目5から項目8)」, 「安心して生活できる (項目9から項目 12)」,「ワクチンを接種しないと新型コ ロナウイルス感染症に罹患する可能性 (項目 13 から項目 
16)」，「自分の命を守ることや自分が重篤な健康状態に なることを予防できる（項目 17から項目 20)」,「周りの 人々の命を守ることや周りの人々が重篤な健康状態にな ることを予防できる (項目 21 から項目 24)」である. 各項 目に対して,刘象者には,「完全に思わない」から「完全 に思う」までの9段階で回答を求めた。

具体的には，「費用負担の容認」と「安全性への信頼」 は,ヘルスビリーフモデルの「障害性」を参考にして作成 した.但し,解析結果の解釈を分かり易くするために,ワク チンを接種することへの動機づけを妨げるのではなく， ワクチンの接種を促すことに対して肯定的に質問した (「付録」を参照)

「安心して生活できる」は, ヘルスビリーフモデルの 「有益性」を参考にして作成した.また,「ワクチンを接種 しないと新型コロナウイルス感染症に罹患する可能性」 は, ヘルスビリーフモデルの概念のである「有益性」と 「罹患性」を考慮して考えた項目であり, 労働者は新型コ ロナワクチンに対して,新型コロナウイルス感染症への 罹患を予防するという「有益性」を意識した因子がある と仮説を立てた.「自分の命を守ることや自分が重篤な健 康状態になることを䂆防できる」と「周りの人々の命を 守ることや周りの人々が重篤な健康状態になることを予 防できる」は, ヘルスビリーフモデルの概念である「有 益性」と「重大性」を考慮して作成した項目であり,死亡 や重篤な健康状態になることを予防する「有益性」を意 識した因子があると仮説を立てた．

本研究の「新型コロナワクチンに対する意識」に関す る項目を作成するにあたり,これらの24つの項目は,へル スビリーフモデルの4つの概念（「障害性」,「有益性」, 「罹患性」,「重大性」）を参考にしたが,完全に一致させ ていない，もし「新型コロナウイルス感染症に罹患すると 思いますか（罹患性）」,「新型コロナウイルス感染症は, 重篤な肺炎になると思いますか (重大性)」などの項目を 含めた場合,これらの項目は「感染症,あるいは病原体そ のもの」に対する意識であり,新型コロナワクチンに対す る労㗢者の意識ではない.ゆえに,本研究では,ヘルスビリ ーフモデルを部分的な参考に留めて, 新型コロナワクチ ンへの意識について焦点を絞り, 調査票を作成した。

属性・基本事項に関して,年齢,性別,勤務形態（正社 員, 正社員以外）,婚姻状態（既婚,未婚）,「新型コロナウ イルスに感染した経験の有無」について質問した.感染経 験のある者と, 感染経験のない者では,新型コロナワクチ ンに対する意識が異なる可能性も考えられた.しかしな がら, 新型コロナウイルス感染症への感染経験のある労 働者は,この研究を実施している段階では,多くないと予 測したため,この項目は感染経験が「ある」と回答した労 働者および,この質問に無回答な労働者がいた場合,解析 対象から外すために作成した。

\section{4) 解析方法}

新型コロナワクチンに対する意識 (「付録」の項目 1 か ら項目 24）に対して, 因子分析（主因子法,プロマックス 回転）を行った. 固有值が1以上の因子を抽出した.また,
因子負荷量の絶対值が,0.4未満の項目は削除した.また， 因子負荷量の絶対值が,2つの因子に対して 0.4 以上の項 目は,解釈を行い易くするために削除したそそして,因子分 析（主因子法,プロマックス回転）を再び行い, 因子名を 付けた.その後, 各因子のCronbachの a係数を求めた.

「新型コロナワクチン接種への動機づけ（「付録」の項 目25)」と各変数との関連性を検討する目的で,年齢に関 して,Pearsonの積率相関係数を求めた. 性別, 勤務形態, 婚 姻状態に関して,マン・ホイットニーのU検定を行った.そ の後,「新型コロナワクチン接種への動機づけ」を目的変 数とし,強制投入法による重回帰分析を行った.説明変数 は, 年齢, 性別, 勤務形態, 婚姻状態,「因子分析で抽出され た各因子」であった。

なお，「因子分析で抽出された各因子」に関して,それ ぞれの因子ごとに因子得点を求めた。そして, Pearsonの

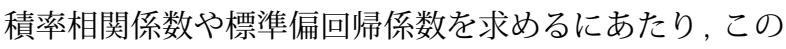
因子得点を解析に使用した。

$\mathrm{P}$ 值が 0.05 未満を統計学的な有意差ありとした.また， 解析には,IBM SPSS Statistics (Version 25.0)を使用した.

\section{5) 解析対象者}

3,968 名の対象者のうち 2,315 名が調査票に回答した （回収率：58.3\%）。年齢, 性別,勤務形態, 婚姻状態、「新型 コロナワクチンに対する意識と新型コロナワクチンを受 けることに対する動機づけ（「付録」の項目 1 から項目 25)」の中で, 243名分の調查票に 1 つ以上の欠損值があ ったことから,これらの調査票を解析対象から外した.さ らに,「新型コロナウイルスへの感染経験の有無」に関し て,「あり」と回答したものが 6 名おり,この項目に無回 答な方が 5 名いた。この 11 名の調査票も解析対象から外 した.その結果,解析対象は 2,061名であった。

男性が 1,404名,女性が657名であった.解析対象者全体 の平均年齢は,47.2歳（標準偏差 13.5）であった.男性の 平均年齢が 48.3 歳（標準偏差 13.7）, 女性の平均年齢が 45.0歳（標準偏差 12.9）であった.

\section{6) 倫理的配慮}

四日市看護医療大学の研究倫理委員会にて承認を得て から,調査を実施した（承認番号：149）。

\section{3 結果}

表 1 に解析対象者の属性・基本事項と「新型コロナワ クチン接種への動機づけ」のクロス集計を示してい る.「新型コロナワクチン接種への動機づけ」は,「やや 思う」から「完全に思う」までのワクチン接種に肯定的 な回答は $67.2 \%$ であった.年齢に関して, Pearsonの積率 相関係数が 0.120 で,「新型コロナワクチン接種への動機 づけ」と有意な相関が認められた.年齢が高くなるに連れ て,新型コロナワクチン接種への動機づけが,全体的に高 くなっていた、性別,勤務形態,婚姻状態に関して,それぞ れ「新型コロナワクチン接種への動機づけ」との間に有 意差が認められた.性別に関して,男性は「思う」という 回答が $23.2 \%$ と最も多い一方で,女性は「どちらともいえ ない」という回答が $26.9 \%$ と最も多かった.勤務形態に関

Vol. 14, No. 2, pp. 129-139, (2021) 


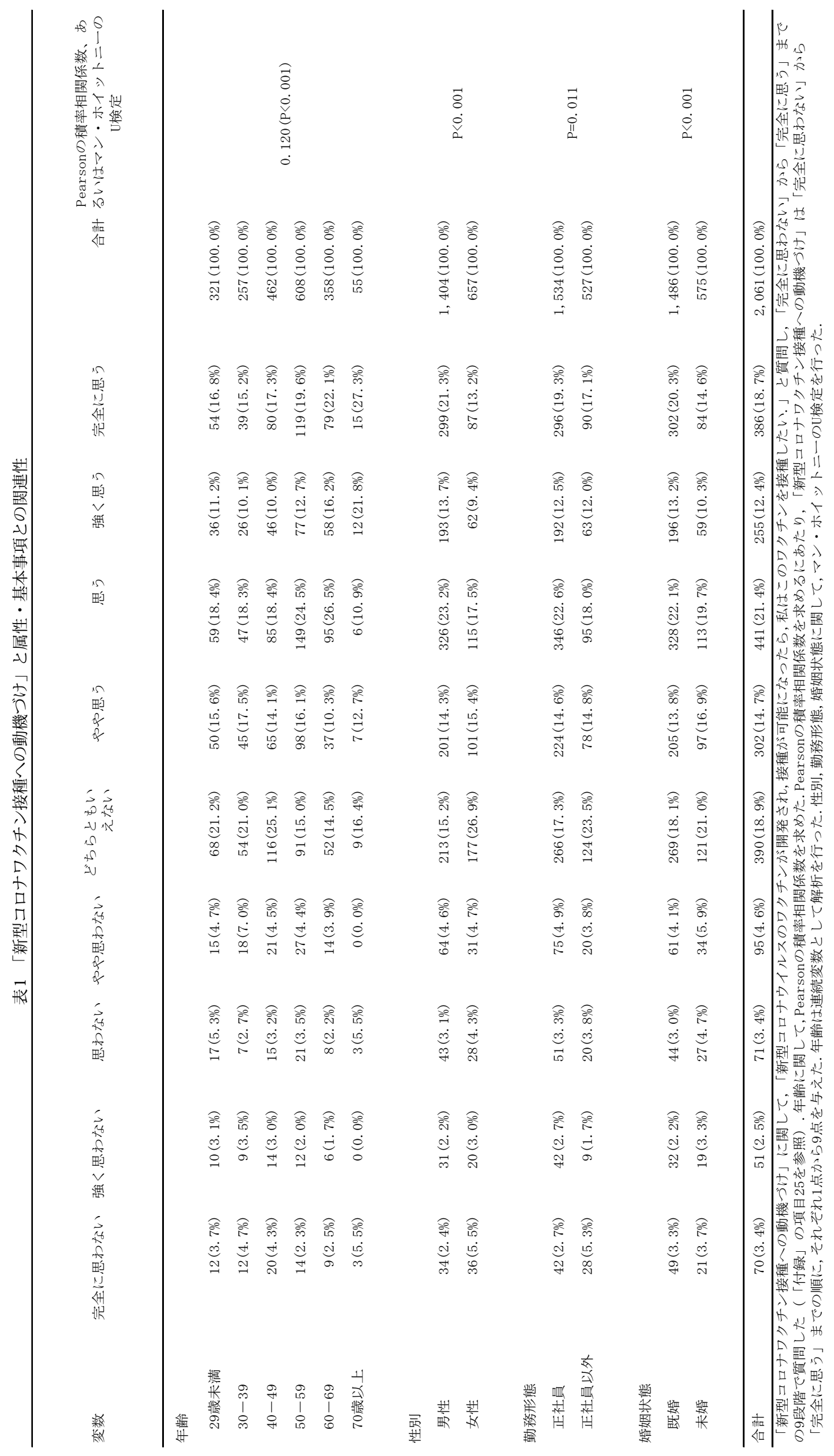


表2＼cjkstart新型コロナワクチンに対する労働者の意識に対する因子分析の結果

\begin{tabular}{|c|c|c|c|c|}
\hline & 第1因子 & 第2因子 & 第3因子 & 第4因子 \\
\hline \multicolumn{5}{|l|}{ 第1因子：自他の命と健康を守れる } \\
\hline 21. 周りの人々の命を守れる & 0.995 & -0.081 & -0.024 & -0.031 \\
\hline 22. 周りの人々の健康を守れる & 0.986 & -0.075 & -0.026 & -0.032 \\
\hline 23. 高齢者の命を守れる & 0.946 & -0.080 & -0.038 & -0.011 \\
\hline 24. 周りの人々を感染させないで済む & 0.939 & -0.071 & -0.008 & -0.010 \\
\hline 18. 重篤な肺炎になるリスクを下げられる & 0.793 & 0.051 & -0.019 & 0.057 \\
\hline 17. 自分の命を守れる & 0.777 & 0.087 & 0.008 & 0.021 \\
\hline 19. 高熱に苦しまないで済む & 0.767 & -0.003 & 0.019 & 0.076 \\
\hline 16. 自肃する生活を送ってもワクチンを接種しないと感染する可能性がある & 0.577 & 0.216 & -0.035 & -0.051 \\
\hline 15. 感染者と接する可能性がある & 0.480 & 0.272 & -0.013 & 0.014 \\
\hline 13. 接種しないと感染する可能性がある & 0.463 & 0.139 & 0.129 & -0.044 \\
\hline \multicolumn{5}{|l|}{ 第2因子 : 費用負担の容認 } \\
\hline 2. 費用負担を惜しまない & $|<0.001|^{\mathrm{a}}$ & 0.944 & -0.001 & -0.029 \\
\hline 3. 費用負担を受容できる & -0.049 & 0.921 & -0.005 & 0.009 \\
\hline 4. 高額であっても費用を支払う & -0.027 & 0.792 & 0.006 & 0.055 \\
\hline 1. 費用を負担する価値がある & 0.176 & 0.704 & -0.023 & -0.018 \\
\hline \multicolumn{5}{|l|}{ 第3因子 : 安心して生活できる } \\
\hline 10. 安心して好きなところに外出できるようになる & -0.115 & 0.006 & 0.977 & -0.031 \\
\hline 9. 自肃しなくて済むようになる & -0.105 & -0.018 & 0.877 & 0.047 \\
\hline 11. 周りの人々が安心して私と接することができるようになる & 0.184 & -0.028 & 0.719 & -0.024 \\
\hline 12. 安心して働けるようになる & 0.286 & 0.028 & 0.579 & 0.026 \\
\hline \multicolumn{5}{|l|}{ 第4因子 : 安全性への信頼 } \\
\hline 6. 体調不良のリスクは低い & -0.024 & -0.024 & -0.033 & 0.942 \\
\hline 7. 障害が残ることはない & 0.024 & 0.002 & -0.031 & 0.858 \\
\hline 5. 副作用が生じることはない & -0.069 & 0.037 & 0.009 & 0.679 \\
\hline 8. 安全性について十分に研究されている & 0.124 & 0.008 & 0.136 & 0.515 \\
\hline \multicolumn{5}{|l|}{ 因子間相関 } \\
\hline & 第1因子 & 第2因子 & 第3因子 & 第4因子 \\
\hline 第1因子：自他の命と健康を守れる & 1 & & & \\
\hline 第2因子 : 費用負担の容認 & 0.553 & 1 & & \\
\hline 第3因子 : 安心して生活できる & 0.524 & 0.314 & 1 & \\
\hline 第4因子 : 安全性への信頼 & 0.418 & 0.356 & 0.496 & \\
\hline
\end{tabular}

a，因子負荷量は正と負の值を取り得るため, 絶対值で示した.

因子分析（プロマックス回転、主因子法）を行うために, 各項目には，「完全に思わない」から「完全に思う」までの順に，それぞれ1点から9点を与え た(「付録」の項目1から24を参照)。その結果, 「14. 生活圈地域で感染者が増えても感染する可能性を下げられる」の因子負荷量の絶対值が 0.4 未満で あったため,削除した.また，「20，長期治療を受けないで済むようになる」が2つの因子に渡り，因子負荷量の絶対值が0.4以上であったため,解釈を分 かり易くするために削除した. その後, 因子分析（プロマックス回転、主因子法）を再び行った.

して,正社員は「思う」という回答が $22.6 \%$ と最も多いが, 正社員以外では「どちらともいえない」という回答が $23.5 \%$ と最も多かった.婚姻状態に関して, 既婚者は「思 う」という回答が $22.1 \%$ と最も多かったが, 未婚者は「ど ちらともいえない」という回答が $21.0 \%$ と最も多かった． 新型コロナワクチンに対する意識（「付録」の項目 1 か ら項目 24）に対して, 因子分析（主因子法,プロマックス 回転)を行った.その結果,「14. 生活圈地域で感染者が増 えても感染する可能性を下げられる」の因子負荷量の絶 対值が 0.4 未満であったため,この項目を削除した.また, 「20. 長期治療を受けないで済むようになる」が2つの因 子に渡り, 因子負荷量の絶対值が 0.4 以上であったため,解
䣋を明確にするために,この項目を削除した。

残りの 22 項目に対して,2回目の因子分析（主因子法, プロマックス回転）を行い,その結果を表2に示した.各 因子名は, 「自他の命と健康を守れる(第1因子)」,「費 用負担の容認(第2因子)」,「安心して生活できる(第3 因子）」,「安全性への信頼（第4因子）」とした. 各因子の 固有值に関して,第 1 因子は 10.056,第 2 因子は 2.493,第3 因子は 2.035 , 第 4 因子は 1.422 であった.この 4 つの因子 で,22 項目の全分散の $72.76 \%$ を説明していた.

次いで,各項目に対して「完全に思わない」から「完全 に思う」までの順に, 1 点から9点を割り当て,表 2 に示し ている各因子のCronbachの $\alpha$ 係数を求めた.その結果,

Vol. 14, No. 2, pp. 129-139, (2021) 


\begin{tabular}{|c|c|c|c|c|}
\hline 変数 & $\begin{array}{r}\text { Pearsonの積率 } \\
\text { 相関係数 }\end{array}$ & P值 & 標準偏回帰係数 & P值 \\
\hline 年齢 & - & - & 0.023 & 0.201 \\
\hline 性別 & - & - & 0.068 & $<0.001$ \\
\hline 勤務形態 & - & - & -0.028 & 0.114 \\
\hline 婚姻状態 & - & - & -0.011 & 0.532 \\
\hline 因子 1：自他の命と健康を守れる & 0.694 & $<0.001$ & 0.481 & $<0.001$ \\
\hline 因子2：費用負担の容認 & 0.644 & $<0.001$ & 0.346 & $<0.001$ \\
\hline 因子 3 : 安心して生活できる & 0.391 & $<0.001$ & -0.017 & 0.357 \\
\hline 因子 4: 安全性への信頼 & 0.388 & $<0.001$ & 0.040 & 0.027 \\
\hline
\end{tabular}

Pearsonの積率相関係数および標準偏回帰係数を求めるために,「新型コロナワクチン接種への動機づけ」は,「完全に思 わない」から「完全に思う」までの順に, それぞれ1点から9点を与えた. 各因子は因子得点を算出して解析に使用した. 年 齢は連続変数として解析を行った. 属性は, 性別 (男性 $=1$, 女性 $=0$ ), 勤務形態 (正社員 $=1$, 正社員以外 $=0$ ), 婚姻状態 （既婚=1，未婚 $=0)$ として解析を行った.

「自他の命と健康を守れる」のCronbachの a係数は 0.945 , 「費用負担の容認」のCronbachの $\alpha$ 係数は 0.917 ,「安心 して生活できる」のCronbachの a係数は 0.891,「安全性

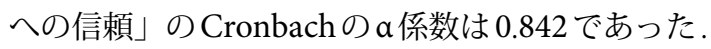

表 3 にPearsonの積率相関係数と重回帰分析の結果を 示している.「新型コロナワクチン接種への動機づけ」は, 「自他の命と健康を守れる」,「費用負担の容認」,「安心 して生活できる」,「安全性への信頼」と有意な正の相関 があった.重回帰分析を行った結果,「安心して生活でき る」は,「新型コロナワクチン接種への動機づけ」との間 に,正の相関が有意に認められていたものの,標準偏回帰 係数は一 0.017 で,P值は 0.357 となり,有意な変数でなか った.そして,自他の命と健康を守れると思っているほど, 費用負担を容認できると思っているほど, 安全性に信頼 しているほど,新型コロナワクチン接種への動機づけが 有意に高かった.男性は,女性と比較して, 新型コロナワク チン接種への動機づけが有意に高かった.重回帰分析の 自由度修正済み決定係数は, 0.576 であった.VIF （Variance Inflation Factor）の值は,全ての変数において 2末満であった。

\section{4 考察}

新型コロナワクチンに対する意識に対して因子分析を 行った.その結果, 「自他の命と健康を守れる」,「費用負 担の容認」,「安心して生活ができる」,「安全性への信 頼」という因子が抽出された.そして, 重回帰分析の結果, 「自他の命と健康を守れる」,「費用負担の容認」,「安全 性への信頼」という3つの因子と性別が，「新型コロナワ クチン接種への動機づけ」と有意に関連していた.

「方法」で述べた通り，「ワクチンを接種しないと新型 コロナウイルス感染症に罹患する可能性」,「自分の命を 守ることや自分が重篤な健康状態になることを予防でき る」,「周りの人々の命を守ることや周りの人々が重篤な 健康状態になることを予防できる」に関して,それぞれ異
なる因子として抽出されると仮説を立てた.しかしなが ら,「自他の命と健康を守れる」という同一の因子として 抽出された.労働者は,新型コロナワクチンに対して,新型 コロナウイルス感染症に罹患した場合に,自分自身の命 を守り, 健康を守るという効果のみでなく, 周りの人々へ の命や健康を守ることへの配慮も同時に意識しており， 自分と他者の命と健康を守るための予防効果を切り離し て考えていないのではないかと思われる。

「自他の命と健康を守れる」が,「新型コロナワクチン 接種への動機づけ」と有意に関連していた. 新型コロナ ワクチンは, 人類が初めて経験するワクチンであるため, このワクチンの有益性に疑問を感じている労働者もいる と考える.労働者に新型コロナワクチンの説明を行う際, このワクチンを接種することは, 自分自身の命や健康を 守る効果のみではなく, 周りの人々の命や健康を守れる ことについても同時に説明することで, 労働者の新型コ ロナワクチンを接種する動機づけは, 高まることが示唆 されたと考える.労働者にワクチンの接種を促す場合, こ の点に留意することで,労働者の新型コロナワクチン接 種への動機づけは高まると考える.

なお,海外では,ヘルスビリーフモデルを活用し,新型コ ロナワクチンを接種する意思に関連する心理的な因子を 探る研究が報告されており,「新型コロナウイルスに罹患 した場合の重大性」と「新型コロナワクチンの有益性」 が, 人々のワクチンを受ける意思にそれぞれ有意に関連 していた ${ }^{11}$.また,Detocらはへルスビリーフモデルを活用 した研究は行っていないものの, 新型コロナウイルス感 染症に感染するリスクを感じていること,および新型コ ロナウイルス感染症への恐怖心を感じているという人々 の心理が,それぞれ,ワクチンを接種する意思に有意に関 連していることを報告している ${ }^{12)}$.これらの心理因子は， それぞれ,ヘルスビリーフモデルの「罹患性」および「重 大性」と解釈できると考える.

本研究では,「新型コロナワクチンへの意識」を調べる 
ことに焦点を当て,ヘルスリーフモデルを参考にして こ れらの意識を把握する項目を独自に作成したものの,「方 法」で説明した通り,「罹患性」,「重大性」,「有益性」, 「障害性」というそれぞれ4つの概念に分けて項目を作成 しなかった.ゆえに,研究デザインが異なることから,これ らの海外の研究 ${ }^{11.12)}$ と本研究の結果との単純な比較はで きない。

しかしながら, 産業保健を推進する人々にとって,これ ら海外の先行研究 ${ }^{11.12)}$ も参考にできると思われる.すなわ ち,産業保健を推進する人久は, 「自他の命と健康を守れ る」という本研究で得られた結果に加えて, 新型コロナウ イルスへの感染のしやすさ（罹患性）やこのウイルスに 感染した場合,重篤な健康状態をもたらすこと（重大性） など, 新型コロナ感染症の性質そのものについても, 労働 者に指導することが有益であると考える.

「費用負担の容認」が，「新型コロナワクチン接種への 動機づけ」と有意に関連していた.費用負担を容認できる 労働者ほどワクチン接種への動機づけが高まる一方で, 費用負担を容認できない労働者は動機づけが低い.特に, 新型コロナウイルス感染症は, 我が国の経済状況に悪影 響を与えている ${ }^{13)}$.したがって, 経済的な理由で新型コロ ナワクチン接種の費用を容認できない労働者もいると考 える.費用負担は,ヘルスビリーフモデルにおける「障害 性」に該当するが,費用を受容できない労働者にとって, ワクチン接種を促す動機づけに対して大きな障害とな る.政府は全額公費で新型コロナワクチンを無料で接種 できるようにすることを決定したが ${ }^{4)}$,この政策は費用を 受容できない労働者の障害性を取り除き,ワクチン接種 への動機づけを高めることになると考える.労働者にワ クチンの接種は無料であることを徹底的に周知する必要 がある。

現在, 新型コロナワクチンは, 自治体が接種の実施主体 である ${ }^{4)}$.ゆえに, 現時点では事業場の判断で接種会場を 自由に決めることが出来ない.また, 今後, ワクチン接種 への機会が整えられ,職場での接種が出来るようになる 可能性もある.しかしながら, 中小・零細事業場では, 医療 専門職者を雇用しておらず,職域での予防接種を行うこ とが困難であるかもしれない.この場合,このワクチン接 種を希望する中小・零細事業場の労働者は, 自治体の指定 する接種会場にて,このワクチンの接種を受けるように なるかもしれない.

労働者が新型コロナワクチンを接種するために接種会 場に行く場合, 労働者が,わざわざ事業場に休暇申請をし たり,交通費を自己負担することも,労働者にとって新型 コロナワクチンを接種する動機づけの「障害性」になる 可能性がある.労働者が接種会場に行くことを職務の一 環として認めることで,出張と同じ扱いにし, 交通費を支 給することも労働者の新型コロナワクチンを接種する動 機づけを高めるかもしれない.このような方策も労働者 にワクチン接種を促す 1 つアイデアになると考える

「安全性への信頼」が,「新型コロナワクチン接種への 動機づけ」と有意に関連していた.安全性に対する信頼の
欠如は,ヘルスビリーフモデルにおける「障害性」に該当 する.ワクチンの安全性への信頼がない下では,人々にワ クチン接種への恐怖心を高めてしまうと推測される、へ ルスビリーフモデルを活用した海外の先行研究でも, 新 型コロナワクチンに対する主観的な有害性への懸念は， 人々のワクチンを接種する意思を妨げる因子である ${ }^{11)}$. そのため, 産業保健を推進する人々は, 労働者にワクチン が承認されるまでのプロセスなどを丁寧に説明すること が重要である.

他方で,ワクチンは,副反応を完全に取り除くことが難 しいことから,リスクはゼロでない ${ }^{14)}$. 医療の専門家は,労 働者に対してリスクに関する丁寧な説明を行い,自己の 意思決定を尊重できるようにすることが必要だと考えら れる.同時に,倫理的な配慮として,労働者に対して, ワク チンを接種してはならないという強制的な䛊解を与えな いようにしなければならない。

労働者にワクチン接種に伴う有害事象が生じた場合, 当該労働者への対応方法を事業場として検討する必要が あると考える.例えば,佐藤らは,任意接種であるインフル エンザワクチンを企業内診療所において, 社員に接種す る試みを報告している ${ }^{15)}$.この報告では,インフルエンザ ワクチンを企業内診療所での接種を労働者に促すにあた り, 医療事故防止と副反応への対応の重要性を指摘して いる.そして,彼らは,ワクチンの接種後の労働者の安全に 関する情報収集に努め,重篤な副作用の発現や医療事故 が無かったことを報告している.すなわち,インフルエン ザワクチンの接種を労働者に進めるのみではなく, ワク チンの接種後の経過についても把握するように努めてい ることから,労働者への安全への配慮が適切に行われて いると考える.

この報告 ${ }^{15)}$ は,新型コロナワクチン接種を労働者に奨 励する場合にも, 参考になるように思われる.事業場とし て労働者の新型コロナワクチン接種に伴う医療事故や副 反応の有無について把握するように努め,もしこれらの 有害事象が生じた場合,必要に応じて医療機関の紹介先 について検討することや有害事象の生じた労働者に休㗇 を認めるなど労働者への安全を配慮した行動が求められ ると考える。

女性は,男性と比較して,新型コロナワクチン接種への 動機づけが低かった.わが国では,2013年 4 月からヒトパ ピローマウイルスワクチン (HPVワクチン) が, 改正予 防接種法において定期予防接種の対象となったものの, 持続的な疼痛などの有害事象がマスメディアで報じら れ,さらに2013年6月に厚生労働省は積極的な接種奨励 を一時中断したという過去がある ${ }^{16,17)}$. 村澤らは,このよ うな有害事象の報告を受けて,女子看護学生に対してア ンケート調査を行い,HPVワクチンを「接種したくない」

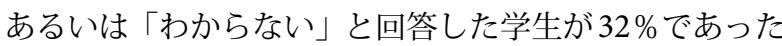
と報告している ${ }^{16)}$.さらに,彼らの調査では,その理由とし て「メディアで副作用の問題を知って」,「副作用がこわ い」,「もっと安全と知ったうえで接種したい」であった と報告している.

Vol. 14, No. 2, pp. 129-139, (2021) 
村澤らの報告 ${ }^{16)}$ では, 医療系の学問を学んでいない女 性の意見は反映されていないため,解釈に注意が必要で あるが,参考になる.我が国では,女性を対象としたワクチ ンにおいて, 梁刻な有害事象がマスメディアを通して大 きく報道された過去があることから，女性は男性よりも， 新しいワクチンの接種による有害事象に対する怖さや警 戒心を持っている可能性がある。

その他,今回の調査では,女性に対して,妊娠の有無や妊 娠の希望の有無について質問をしていない.もし,今回の 調查対象に妊娠をしている女性や，妊娠を希望をしてい る女性が多く含まれていた場合,胎児への影響や妊娠へ の悪影響を懸念し,新型コロナワクチンへの接種を控え たいと考えている可能性もある.

本研究は,新型コロナワクチンの承認前に集めたデー タの解析結果である.今後,新型コロナワクチンの有害報 告がほとんどない,あるいは少ないことが国民に広く認 識されれば,性差による統計学的な有意差がなくなった り,逆に女性は男性よりもワクチン接種に有意に積極的 になる可能性もある.今後, 時系列的に性差による動機づ けへの違いを調査していく必要もある.

今回の研究デザインは,横断研究であるため, 因果関係 を特定できていないことが本研究の限界である.また, 無 作為抽出法を用いていないため,一般化の範囲が限定さ れていることも限界である。

「自他の命と健康を守れる」という因子が抽出された結 果は,職域での調查でのみ見られる結果ではなく,わが国 の国民性を反映している可能性も高い. 今後, 学生や定年 退職者など労働者以外の人々を対象にした研究データの 蓄積も必要であると考える.他方で,この因子が職域での み見られる特有の因子である可能性もある.この場合, 他 者と一緒に仕事を行う機会が少ない労働者のみを対象と した場合, 本研究とは異なる因子が抽出されるかもしれ ない.このように,労働環境己゙とに,因子分析で抽出される 因子が異なるのか検討する必要がある.

また,本研究は,「新型コロナワクチンに対する意識」を 調査したが,「自他の命と健康を守れる」という因子は, この感染症に対する様々な予防的な保健行動にも応用で きる可能性があると考える.例えば,職域で手洗いを励行 することの「有益性」を労働者に指導する場合, この行動 が,自分の命や健康を守るのみではなく, 周りの人々の命 と健康を守るためにも重要であることを強調すること で, 効果的に労働者に行動変容を促せる可能性があると 考える.同様に,「マスクの着用」,「室内の換気を行う」, 「大人数での会食を控える」など様々な予防的保健行動の 「有益性」を労働者に促す場合, これらの予防的保健行動 が,自分自身の命と健康を守るのみではなく, 周りの人々 の命と健康を守れることを強調することで,効果的な指 導になるかもしれない,さらに,「自他の命と健康を守れ る」という因子が我が国の国民性を表しているのであれ ば,国民全体に対して行動変容を促すことにも応用でき る.今後の検討課題としたい.

本研究では「新型コロナウイルス感染症に罹患すると思
いますか（罹患性）」,「新型コロナウイルス感染症は,重 篤な肺炎になると思いますか (重大性)」などへルスビリ 一フモデルにおける「罹患性」や「重大性」の概念を分析 していない.他方で,これら「罹患性」や「重大性」の概念 は,「ワクチンを接種しないと新型コロナウイルス感染症 に罹患する可能性（項目 13から項目16）」, 「自分の命を守 ることや自分が重篤な健康状態になることを予防できる (項目 17から項目 20)」, 「周りの人々の命を守ることや周 りの人々が重篤な健康状態になることを予防できる (項目 21から項目 24)」と比較的に類似する概念である.

したがって,「罹患性」や「重大性」に関する項目を本 研究の解析に含めた場合,解釈が明確にならない因子が抽 出されたり,解析結果が複雑になる可能性も考えられ る.もしそうなれば,本研究の知見を社会に還元し難くな る.ゆえに,本研究では,ヘルスビリーフモデルをそのまま 活用する研究ではなく,「労働者のワクチンに対する意識」 のみに焦点を絞り,研究がシンプルになるように努めた。

しかしながら, ヘルスビリーフモデルの「罹患性」や 「重大性」の概念は, 予防的保健行動に重要な視点である と思われるため,今後,我が国の労働者においても,ヘルス ビリーフモデルのそれぞれ 4 つの概念に該当する因子が あり,かつ,新型コロナワクチン接種への動機づけに関連 しているという仮説を検証する必要もあると考える.

最後に,重回帰分析の説明変数として,地域差, 事業場の 規模, 事業場での産業医の雇用の有無, 産業看護職の雇用 の有無,基礎疾患の有無,仕事の内容,教育歴,職種など様々 な変数についても検討し,解析を行うことも検討課題で ある。

\section{5 まとめ}

「自他の命と健康を守れる」,「費用負担の容認」,「安 全性への信頼」という3つの因子が「新型コロナワクチ ン接種への動機づけ」と有意に関連していた.また,男性 は,女性よりも新型コロナワクチン接種への動機づけが 有意に高かった.労働者の新型コロナワクチンの接種率 を高めることは,職域における感染拡大を防ぐ,有益な手 段になる.これらの心理的な因子や性別の違いを考慮す ることで,労働者の新型コロナワクチン接種の動機づけ を高めることが出来る.

\section{利益相反}

本研究を行うにあたり, 著者らに利益相反はない.

\section{謝辞}

本研究にご協力いただきました労働者の皆さまに，心 から感謝いたします.

\section{文献}

1）厚生労㗢省.新型コロナウイルスを想定した「新しい生活 様式」の実践例を公表しました https://www.mhlw.go.jp/ stf/seisakunitsuite/bunya/0000121431_newlifestyle.html (2021年2月 22日) 
2) 清水 英佑, 河野 啓子, 村田 理絵, 安倍 孝治, 新谷 奈苗, 瀬 戸美才, 他. 緊急特集:産業保健スタッフの役割とは? COVID-19第2波に備えるヒント,今後, 産業保健スタッフ にはどのような役割が求められると考えますか? 産業保健 と看護 $2020 ; 12: 453-456$.

3）河野 啓子, 村田 理絵, 加藤 元, 亀田 真紀, 中野 愛子, 新谷 奈苗,他. 緊急特集:産業保健スタッフの役割とは? COVID-19第2波に備えるヒント, 今後, 第2波・第3波が来 ることを想定しどのような備えが必要だと考えますか? 産 業保健と看護 2020;12:449-452.

4）厚生労働省.健発1209第2号 予防接種法及び検疫法の一部 を改正する法律等の施行について https://www.mhlw.go.jp/ hourei/doc/tsuchi/T201210G0070.pdf（2021年2月22日）

5）峰宗太郎,山中浩之.「第3 章 核酸ワクチンへの期待と不 安」、『新型コロナとワクチン 知らないと不都合な真実』.東 京:日経BPマーケティング;2020:85-120.

6) Kudo $Y$, Satoh $T$, Kido $S$, Ishibashi M, Miyajima E, Watanabe $\mathrm{M}$, et al. The degree of workers' use of annual health checkup results among Japanese workers. Ind Health 2008;46:223-232.

7) Kudo Y, Okada M, Tsunoda M, Satoh T, Aizawa Y. Predictors of Japanese workers' motivation to use the results of worksite health checkups in their daily health management. Tohoku J Exp Med 2009;219:231-241.

8) Kudo Y, Okada M, Tsunoda M, Satoh T, Aizawa Y. A lifestyle to prevent or combat the metabolic syndrome among Japanese workers: analyses using the health belief model and the multidimensional health locus of control. Ind Health 2011;49:365-373. Ind Health. Erratum in: 2011;49:543.

9) Nexøe J, Kragstrup J, Søgaard J. Decision on influenza vaccination among the elderly. A questionnaire study based on the Health Belief Model and the Multidimensional Locus of Control Theory. Scand J Prim Health Care 1999;17:105-110.

10) Myers LB, Goodwin R. Determinants of adults' intention to vaccinate against pandemic swine flu. BMC Public Health 2011;11:15.

11) Wong MCS, Wong ELY, Huang J, Cheung AWL, Law K, Chong MKC. et al. Acceptance of the COVID-19 vaccine based on the health belief model: A population-based survey in Hong Kong, Vaccine 2021; 39:1148-1156.

12) Detoc M, Bruel S, Frappe P, Tardy B, Botelho-Nevers E, Gagneux-Brunon A. Intention to participate in a COVID-19 vaccine clinical trial and to get vaccinated against COVID-19 in France during the pandemic. Vaccine 2020; 38:7002-7006.

13）内閣府.令和 2 年度 年次経済財政報告 (経済財政政策担当 大臣報告）一コロナ危機：日本経済変革のラストチャンス — https://www5 .cao.go.jp/j-j/wp/wp-je20 /index.html （2021年2月 22 日）

14）日本感染症学会.「COVID-19ワクチンに関する提言」に際 して https://www.kansensho.or.jp/modules/guidelines/ind ex.php?content_id=43（2021年2月22日）
15）佐藤 潤一, 酒井 伸夫, 新田 昭彦. 海外派遣企業におけるイ ンフルエンザに対する取り組み インフルエンザワクチ ンの企業内集団的接種の実践. 細胞 2009; 41:581-586.

16）村澤 秀樹, 大久保一郎, 今野 良, 荒川一郎. 女子看護学生 の子宮頸がん予防に関する意識調査一ワクチンの副反応 報告を受けて一. 厚生の指標 2015; 62: 13-17.

17）宮城悦子, 今野良, 井篦一彦. パピローマウイルス最前 線,HPVワクチン接種後の有害事象とその対策. 医学のあ ゆみ 2016; 258: 159-163.

\section{付録＼cjkstart新型コロナワクチンを受けることに対する動機づ けと新型コロナワクチンに対する意識}

1 . 新型コロナワクチンは,接種にかかる費用を負担するだけ の価值があると思う

2. 私は,新型コロナワクチンの接種にかかる費用を惜しまな いと思う

3 、私は,新型コロナワクチンの接種にかかる費用の負担を受 け入れることができると思う．

4 、私は,仮に新型コロナワクチンの接種に必要な費用が高額 であったとしても,その費用を支払うと思う。

5 . 私は,新型コロナウイルスのワクチンによる副作用が生じ るとは思わない．

6. 私は,新型コロナウイルスのワクチンを接種することで,体 調が悪くなるリスクは低いと思う

7. 私は,新型コロナウイルスのワクチンを接種することで,私 の身体に障害が残ることはないと思う.

8 . 私は,新型コロナウイルスのワクチンの身体への安全性に 対して,十分に研究されていると思う

9. 私は,新型コロナウイルスのワクチンを接種することで,自 肃しなくて済むと思う

10．私は,新型コロナウイルスのワクチンを接種することで,安 心して好きなところに行けると思う。

11. 私が,新型コロナウイルスのワクチンを接種することで,私 の周りの人々が,私と安心して接することができるように なると思う。

12. 私は,新型コロナウイルスのワクチンを接種することで,安 心して働けるようになると思う

13、私は,新型コロナウイルスのワクチンを接種しないと,新型 コロナウイルスに感染する可能性は高いと思う．

14. 私が,新型コロナウイルスのワクチンを接種することで,私 の生活を営んでいる地域で感染者が増えても,感染する可 能性を低く保てると思う

15. 私は,新型コロナウイルスへの感染者と接触する可能性が 考えられるので,新型コロナウイルスのワクチン接種は必 要だと思う

16. 私は,自肃する生活を送るように心がけても,新型コロナウ イルスのワクチンを接種しないと,感染する可能性がある と思う。

17. 私は,新型コロナウイルスのワクチンを接種することで,自 分の命を守ることができると思う

18. 私は,新型コロナウイルスのワクチンを接種することで,重 篤な肺炎になるリスクを下げることができると思う

Vol. 14, No. 2, pp. 129-139, (2021) 
19. 私は,新型コロナウイルスのワクチンを接種することで,高 熱に苦しまなくて済むと思う。

20. 私は,新型コロナウイルスのワクチンを接種することで,長 期間にわたる治療に時間を費やさないで済むと思う

21. 私が,新型コロナウイルスのワクチンを接種することで, 周 りの人々の命を守ることができると思う．

22. 私が,新型コロナウイルスのワクチンを接種することで, 周
りの人々の健康を守ることができると思う．

23. 私が,新型コロナウイルスのワクチンを接種することで, 高 齢者の命を守ることにつながると思う．

24. 私が,新型コロナウイルスのワクチンを接種することで,周 りの人々を感染させないで済むと思う。

25. 新型コロナウイルスのワクチンが開発され,接種が可能に なったら,私はこのワクチンを接種したい. 


\title{
Associations between the attitudes toward the COVID-19 vaccine and the motiva- tion to get vaccinated against COVID-19 among Japanese workers
}

by

\author{
Yasushi Kudo*1, Yuki GotoH*1, Kayoko KakiharA*1, Kazue YoshidA*1, \\ Yoshihiko Enomoto*1, Tomoko Mori*1, Keiko Kono*1 and Akizumi Tsutsumi*2
}

We investigated the associations between the attitudes toward the COVID-19 vaccine and the motivation to receive the COVID-19 vaccine among Japanese workers using an anonymous questionnaire. This study was conducted during the period of September through December 2020. The analyzed subjects were 2,061 workers. Regarding "motivation to get vaccinated against COVID-19," the subjects selected responses from a 9-point scale from "definitely agree" to "definitely disagree." A total of $67.2 \%$ ("definitely agree" to "somewhat agree") workers had the motivation to get vaccinated against COVID-19. Factor analyses revealed four factors regarding their attitudes toward the COVID-19 vaccine: "protecting the lives and health of oneself and others," "agreement to pay for the vaccine," "leading a relaxed live," and "perceived safety." As a result of multiple regression analysis, "protecting the lives and health of oneself and others," "agreement to pay for the vaccine," and "perceived safety" were significantly associated with "motivation to get vaccinated against COVID-19." Males were more motivated to receive the vaccine than females. By considering these three factors and gender differences, workers' motivation to get vaccinated against COVID-19 will be improved. Key Words: COVID-19, motivation, vaccine, worker

*1 Yokkaichi Nursing and Medical Care University, Japan.

*2 Department of Public Health, Kitasato University School of Medicine, Japan. 